Article

\title{
Application of Comprehensive Assessment System for Built Environment Efficiency (CASBEE) at City Level in Johor Bahru
}

\author{
Muhammad Akmal Hakim ${ }^{1}$, Gabriel Hoh Teck Ling ${ }^{1, *}$, Chau Loon Wai ${ }^{1}$ and Chin Siong Ho ${ }^{1}$ \\ 1 UTM-Low Carbon Asia Research Centre, Department of Urban and Regional Planning, Faculty of Built \\ Environment and Surveying, Universiti Teknologi Malaysia, Skudai, 81310 Johor Bahru, Malaysia; \\ akmal_hkm@yahoo.com, lwchau@utm.my, ho@utm.my \\ * Correspondence: gabriel.ling@utm.my
}

\begin{abstract}
CASBEE-City tool determines the city's Built Environment Efficiency (BEE) by calculating the improvement of Quality of Life (Q) over human activities' Environmental Load (L) within the city's hypothetical boundary. A total of 58 variables ( $57 \mathrm{Q}$ indicators and one variable for $\mathrm{L}$ ) are used in the worldwide version of CASBEE-City which were grounded using ISO 37120:2014 Sustainable Development of Communities and 17 Sustainable Development Goals (SDGs) by the United Nations (UN). This paper examines the application of CASBEE-City for Malaysian cities using the case of Johor Bahru City and identifies assessment indicators which are customised based on the data availability, reliability and suitability through focus group discussions (FGDs) which involved 36 respondents (researchers, urban planners and stakeholders). This paper reveals Johor Bahru with moderate score B+ in 2010 and 2025. Consensus were also achieved from the 36 FGD respondents for the practicability and future potential of CASBEE-City and BEE framework in Johor Bahru.
\end{abstract}

Keywords: built environment efficiency; CASBEE; MURNInets; climate change; low carbon; carbon emission; urban tools; city

\section{Introduction}

Countries all over the world have been developing a variety of built environment assessment tools starting with individual buildings such as the Building Research Establishment (BRE) Environmental Assessment Method (BREEAM) in the United Kingdom, the Leadership in Energy and Environmental Design (LEED) system in the United States and the Comprehensive Assessment System for Built Environment Efficiency (CASBEE) in Japan since 1998 [1]. But, none of these assessment tools calculate carbon emission reduction except CASBEE. The carbon emission reduction calculation in sustainable development have been outlined towards quantifying the reduction of global greenhouse gases (GHG) emission which was based in the Kyoto Protocol, 1997 in Japan. With mutual commitment but different approaches, developed countries with high GHG emission rate [2] have been tackling climate change issues by trying to combat carbon emission. Urban developments are responsible for $70 \%$ of national carbon emission [3] thus, making urbanisation as a leading cause for global warming. The latest trend appears to be that the assessments tools are now being developed for a broader context after the experience gained in assessing individual buildings [4]. In 2015, United Nations (UN) have outlined a set of sustainability goals to assess and guide cities and urban developments around the world to pursue sustainable development through a set of 17 Sustainable Development Goals (SDGs) and Sustainable Development of Communities: Indicators for City Services and Quality of Life or (ISO 37120:2014).

In line with the Malaysia's national pledge to reduce $45 \%$ carbon emission intensity by 2030 at Conference of Parties 21 (COP21), Iskandar Malaysia (IM) as an economic region located at the Southern part of Peninsular Malaysia has took the initiative since 2011 to work closely with the local 
and international research universities such as Universiti Teknologi Malaysia (UTM), Kyoto University (KU), Okayama University (OU) and the National Institute for Environmental Studies (NIES) to develop a Low Carbon Society Blueprint for Iskandar Malaysia 2025 (LCSBP-IM 2025). The blueprint which has set a clear carbon intensity reduction targets for IM up to 58\% carbon by 2025 (based on 2005 levels) has provided the promotion of CASBEE under the Action 3 (Low Carbon Urban Governance) within Sub-Section I and Measure 4.1 Promote Green Buildings in New Construction by using CASBEE as alternative assessment tool. CASBEE is planned to be integrated in the planning application submissions of development in Iskandar Malaysia. Since 2015, CASBEE has actively been promoted by its authority, Iskandar Regional Development Authority (IRDA), as a reward or certification for land development projects that meet 'green' or sustainable criteria in the region. CASBEE tool is planned to provide policies and reward development projects that contribute to IM's low carbon society visions. In response to this, the local authorities in Iskandar Malaysia shall implement CASBEE in order to reduce their cities' carbon emissions by setting future sustainable policy targets.

CASBEE has been widely used in Japan via various scale of assessment tools CASBEE-Buildings for individual buildings, CASBEE-Urban Development for urban compound and CASBEE-City for cities/municipalities by calculating the built environment efficiency performance in over 1500 Japanese cities, since 2011. The basic concept of CASBEE applies “a unique assessment framework that takes into account the concept of environmental efficiency which is different from a simple summation of points or credits awarded in all performance area" [5]. This type of environmental efficiency assessment framework provides a different insight into the built environment performance assessment compared with conventional assessment methods [1]. CASBEE considers the efficiency improvement of built environment by calculating the comprehensiveness of Built Environment Efficiency (BEE) through dividing the increase Quality of Life (Q) indicators with the reduction of carbon emission or Load (L) emitted outside of city's boundary. With the success of CASBEE-City in Japan, it has brought to the expansion of the assessment for worldwide cities use. CASBEE-City worldwide version was developed in 2015 and its assessment indicators comprises of international indicators developed from the Sustainable Development Goals (SDGs) and ISO 37120:2014 Sustainable Development of Communities (ISO) by the United Nations (UN).

In comparison with the existing and widely used urban sustainability assessment tool in Malaysia, Malaysian Urban-Rural Indicators Network for Sustainability (MURNInets), it is questionable if CASBEE-City overall assessment methodology can be accepted by the local authorities and stakeholders for implementation. In record, MURNInets is a rating based assessment (simple summation of points/credits) and has been used to assess sustainability in most Malaysian cities including Peninsular, Sabah and Sarawak area. The policies and guidelines on the assessment have been outlined by the Town and Country Planning Department of Peninsular Malaysia (JPBD Peninsular Malaysia) for the Malaysian cities to assess sustainability. Thus, the purpose of this research is to explore substantially by investigating the customisation of CASBEE-City, an international urban sustainability assessment tool in the context of Malaysian cities using the case study of Johor Bahru in Iskandar Malaysia. To emphasis, evaluating built environment sustainability without considering carbon emission reduction calculation may not sound valid or accurate. Thus, having CASBEE concept to quantify carbon emission especially for cities can picture a better city's environment efficiency performance. This paper would like to contribute in helping local authority especially urban planners to find exposure as well as providing alternative in the field of urban sustainability assessment tools in Malaysia based on CASBEE-City assessment indicators and methodology. This research is vital as it will add additional value in the existing Malaysian urban sustainability assessment framework. 


\subsection{Study Area}

The city of Johor Bahru in Iskandar Malaysia is selected as a sole case to study the application of CASBEE-City based on its distinct characteristics, functions, location and vision to become an international city by the year 2020. Johor Bahru can be categorised as an emerging commercial city (developing city). It is a primary city centre in Johor and Iskandar Malaysia, the second largest conurbation in Malaysia after Klang Valley, followed by Penang conurbation. This paper will provide an early exploration of CASBEE-City methodology in the context of Malaysian cities using the case of Johor Bahru City. Figure 1 shows the location of Johor Bahru within Zone A as a Financial Hub and City Centre of Iskandar Malaysia economic region.

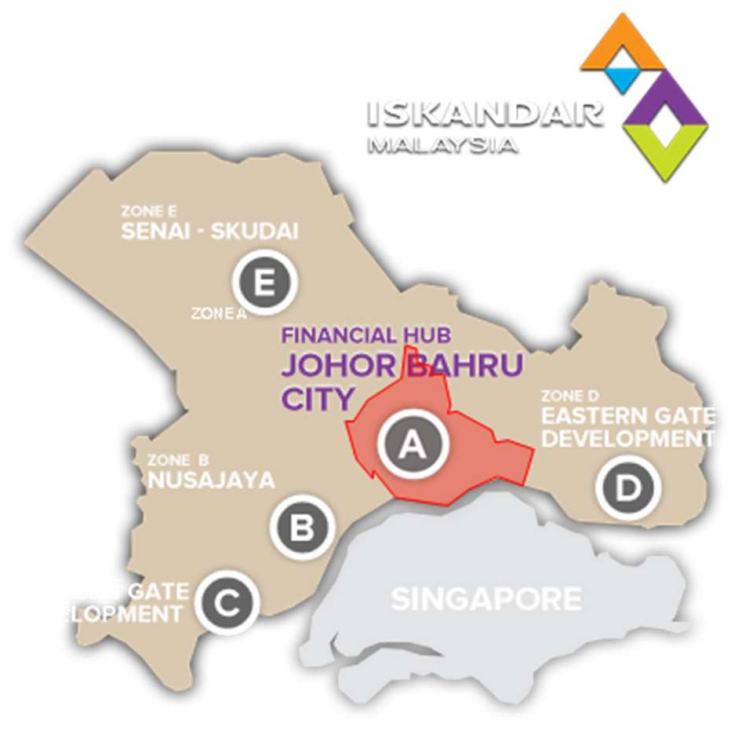

Figure 1. Johor Bahru in Zone A - Financial Hub Iskandar Malaysia

\section{Urban Sustainability Assessment Tools}

The theoretical framework reviews start with the basic understanding of urban sustainability assessment theories. It is then related with the agenda of sustainable development that brought upon the development of CASBEE-City tools. CASBEE-City tool is then compared with the MURNInets to provide and overall relation based on their methodology, assessment indicators and weightage.

\subsection{Indices Development}

In developing indicators for assessment, there are certain criteria that are researchers and tool developers can justify to establish a good set of assessment indicators for a certain area. Based on various literatures, the following are criteria recommended to be evaluated before selecting indicators for an urban sustainability assessment. In the process of selecting suitable assessment indicators, only those indicators that can describe the best on sustainable development comprehensively are selected. Indicators do not usually cater to the scientific demand, they must be seen as a symbol of best knowledge achieved [6]. Availability and trustworthiness of data is a very important factor and plays a very important role to ensure good index (indicators) development and application [7]. All sustainability index formation must be in effective cost. No matter how good the theoretical construction of an index, it is only useful if key indicator development is at a reasonable cost [8]. Indicators should be easily understood by citizens without professional knowledge, while being precise and easily to apply [9]. Indicators should be based on data that have sufficient high-quality information [7]. The value of index or indices normally falls within the range of 0 to 1 , whereas a value closer to 1 
denotes better sustainable development and the value closer to zero denotes poor sustainable development [10].

\subsection{CASBEE-City (W) Assessment Indicators}

Selection of assessment indicators in CASBEE-City $(\mathrm{W})$ assessment are made by referring the latest UN's indicators under 17 SDGs Goals and a set of 100 international standardised indicators from ISO 37120:2014 through data availability, simplicity, validity, policy relevance and balance. 58 candidate assessment indicators from SDGs and ISO are finalised to be included into CASBEE-City (W) assessment system.

\subsection{Reviewing Urban Sustainability Assessments}

Table 2 simplifies all the reviewed urban assessment indicators and tools in the literature reviews according to the aspects that each of them has and does not has ( 1 denotes for provided and 0 for none). Researcher has put the total score for each assessment indicators or tool to provide clear significance value of strength which each assessment has.

Table 1. Reviews of urban sustainability assessments and their consideration aspects.

\begin{tabular}{|c|c|c|c|c|c|c|c|}
\hline \multirow[b]{2}{*}{ Name } & \multicolumn{6}{|c|}{ Aspects of Consideration } & \multirow{2}{*}{$\begin{array}{c}\text { Total } \\
\text { Marks }\end{array}$} \\
\hline & Economy & Social & Environment & $\begin{array}{c}\text { Equal } \\
\text { Weightage }\end{array}$ & $\begin{array}{c}\text { Carbon } \\
\text { Reduction }\end{array}$ & $\begin{array}{c}\text { Global } \\
\text { Validity }\end{array}$ & \\
\hline Compass & & & & & & & \\
\hline $\begin{array}{c}\text { Index of } \\
\text { Sustainability }\end{array}$ & 1 & 1 & 1 & 1 & 0 & 0 & 4 \\
\hline $\begin{array}{l}\text { Sustainable } \\
\text { Cities Index }\end{array}$ & 0 & 1 & 1 & 1 & 0 & 0 & 3 \\
\hline $\begin{array}{l}\text { Ecosistema } \\
\text { Urbano } \\
\text { Performance } \\
\text { Index }\end{array}$ & 1 & 1 & 1 & 0 & 0 & 0 & 3 \\
\hline MURNInets & 1 & 1 & 1 & 1 & 0 & 0 & 4 \\
\hline $\begin{array}{c}\text { CASBEE-City } \\
\text { (W) }\end{array}$ & 1 & 1 & 1 & 1 & 1 & 1 & 6 \\
\hline
\end{tabular}

Source: Author's literature reviews.

Based on Table 2, researcher can conclude that CASBEE-City (W) has the highest total marks which covers all the aspects in consideration mentioned in the table such as economic, environment, social, equal weightage, carbon emission reduction and global validity (based on the validity of the assessment indicators to be used outside of a certain area or region).

\section{Research Methodology}

Particular methods have been selected to provide answers for each research question (RQ) and objective (RO). Table 2 simplifies the RQs and ROs, its description and method used to acquire data, analysis and findings accordingly. 
Table 2. Methods used for RQ and RO.

\begin{tabular}{|c|c|c|}
\hline $\mathrm{RQ} / \mathrm{RO}$ & Description & Method \\
\hline RQ1/RO1 & $\begin{array}{l}\text { RQ1: How to incorporate and further } \\
\text { improve CASBEE-City (W) as part of } \\
\text { MURNInets? } \\
\text { RO1: To incorporate and further } \\
\text { improve CASBEE-City (W) as part of } \\
\text { MURNInets. }\end{array}$ & $\begin{array}{ll}\text { i. } & \text { Literature reviews } \\
\text { ii. } & \text { Focus group discussions } \\
& \text { (FGDs) } \\
\text { iii. } & \text { Knowledge exchange from } \\
& \text { CASBEE developers and } \\
& \text { researchers (IBEC, Keio \& } \\
& \text { Hosei University) }\end{array}$ \\
\hline RQ2/RO2 & $\begin{array}{l}\text { RQ2: What are the customised CASBEE- } \\
\text { City (W) Quality (Q) and Load (L) } \\
\text { assessment indicators determined for } \\
\text { Johor Bahru? } \\
\text { RO2: To develop the customised } \\
\text { CASBEE-City (W) Quality (Q) and Load } \\
\text { (L) assessment indicators for Johor } \\
\text { Bahru. }\end{array}$ & $\begin{array}{ll}\text { i. } & \text { Literature reviews } \\
\text { ii. } & \text { FGDs }\end{array}$ \\
\hline RQ3 / RO3 & $\begin{array}{l}\text { RQ3: What is the Built Environment } \\
\text { Efficiency (BEE) value for Johor Bahru } \\
\text { using CASBEE-City }(W) \text { ? } \\
\text { RO3: To conduct assessment using Johor } \\
\text { Bahru CASBEE-City (W) as an } \\
\text { exploratory case. }\end{array}$ & $\begin{array}{l}\text { i. Deskwork: } \\
\text { Data collection: open-source } \\
\text { statistical data, professional } \\
\text { assumptions/calibration } \\
\text { ii. Data input: } \\
\text { CASBEE-City }(W) \text { Excel software } \\
\text { tool analysis }\end{array}$ \\
\hline RQ4/RO4 & $\begin{array}{l}\text { RQ4: What are the views and feedback } \\
\text { of the professionals and stakeholders on } \\
\text { CASBEE-City }(W) \text { ? } \\
\text { RO4: To propose a customised CASBEE- } \\
\text { City (W) model as an alternative urban } \\
\text { sustainability assessment tool in Johor } \\
\text { Bahru and Malaysian cities. }\end{array}$ & $\begin{array}{ll}\text { i. } & \text { Deskwork } \\
\text { ii. } & \text { Literature reviews } \\
\text { iii. } & \text { FGD }\end{array}$ \\
\hline
\end{tabular}

Source: Author's literature reviews.

\subsection{Focus Group Discussion (FGD)}

A total number of 32 stakeholders, professional urban planners and experts participated in (2) FGD sessions which consist of professionals and experts from various background such as health and environment, landscape developer, urban planning, geographic and management. Their work experiences ranging from 5 to 33 years and are represented from the local governments, private sectors and research bodies (e.g. Johor Bahru City Council (MBJB), Johor Bahru Tengah Municipal Council (MPJBT), Kulai Municipal Council (MPKu), Johorland Berhad, UTM researchers, Keio University, Hosei University, Institute of Built Environment Efficiency for Conservation (IBEC) and Iskandar Regional Development Authority (IRDA). As all of the indicators in CASBEE-City (W) are equally weighted, the survey to determine the weightage for each of the indicators were not conducted.

\subsection{CASBEE-City (W) Assessment Analysis}

The assessment was conducted using the pilot version of CASBEE-City (W) excel software by inputting all of the data for $\mathrm{Q}$ and $\mathrm{L}$ assessment indicators. CASBEE-City (W) assessment uphold Built Environment Efficiency (BEE) calculation by dividing the score of Quality $(\mathrm{Q})(\mathrm{Q} 1=$ Environment, $\mathrm{Q} 2=$ Social, Q3= Economic) factors over the reduction of Load (L). The BEE for Johor Bahru is calculated using the following equation 1 containing the total of $Q$ and $L$ scores on a 100-point scale: 


$$
\text { Built Environment Efficiency }(\mathrm{BEE})=\underline{\text { Score of Quality }(\mathrm{Q})}=\underline{25 \times(\mathrm{SQ}-1)}
$$

$$
\text { Score of Load (L) L }
$$

The Quality (Q) assessment indicator calculation; the distribution of the original index values will be used to draw a cumulative relative frequency curve that serves as a reference for setting the baseline and boundaries between levels for each assessment indicator [5,11]. A base score is determined based on the continuous curve. An individual score on a scale of 1.0 to 5.0 is calculated by multiplying the base score by 4 then adding 1. Finally, an overall Q score (SQ) on a scale of 1.0 to 5.0 is calculated by multiplying the base score by 4 and then adding 1 . Calculation of the total BEE score requires $Q$ scores on a scale of up to 100 for the numerator and denominator. SQ value is subtracted by 1 and then multiplied by 25 .

For environmental load (L) score calculation, index values are obtained by calculating the annual greenhouse gas emissions per capita ( $\mathrm{t}-\mathrm{CO}_{2} /$ person/year) using the adjusted population. A total score on a scale of 0 to 100 is calculated by applying a logistic function where the national emission average per capita $\left(10 \mathrm{t}-\mathrm{CO}_{2} /\right.$ person/per year) is represented as a median value of 50 . Scores of the $\mathrm{L}$ items are also calculated on a scale of 1.0 to 5.0 .

\section{Research Findings}

\subsection{Identified Customised Assessment Indicators for Johor Bahru}

The finalised assessment indicators were determined after extensive session of FGDs with the experts, stakeholders and professional urban planners. The selection were also based on the characteristics of assessment indicators (i.e. reflective, availability, continuity and trustworthiness, affordability, simplication and quantifiable) [6-10], the determined assessment indicators from the FGDs are further evaluated by researcher to produce a finalised set of CASBEE-City (W) assessment indicators which are ready for assessment and data input. Table 3 shows the determined customisation of CASBEE-City (W) assessment indicators for Johor Bahru.

\begin{tabular}{|c|c|c|}
\hline No. & Assessment Indicators & Customisation \\
\hline 1. & $\begin{array}{c}\text { Mean urban air pollution of particulate } \\
\text { matter (PM2.5) }\end{array}$ & $\begin{array}{l}\text { Suggestion to use PM10 as currently } \\
\text { no data are available for PM2.5 for } \\
\text { Malaysian cities. }\end{array}$ \\
\hline 2. & $\begin{array}{l}\text { Availability and implementation of a } \\
\text { transparent and detailed deep } \\
\text { decarbonisation strategy, consistent } \\
\text { with the 2oC - or below - global carbon } \\
\text { budget, and with GHG emissions } \\
\text { targets for 2020, } 2030 \text { and } 2050 .\end{array}$ & $\begin{array}{l}\text { Simplified according to local context } \\
\text { as: } \\
\text { Availability of Low Carbon Society } \\
\text { Action Plan with GHG emission } \\
\text { targets for } 2020-2030 \text {. }\end{array}$ \\
\hline 3. & $\begin{array}{l}\text { Proportion of population below } \$ 1.25 \\
\text { Purchasing Power Parity (PPP) per day }\end{array}$ & $\begin{array}{l}\text { There is a need of currency exchange } \\
\text { from Dollars (\$) to Malaysian } \\
\text { Ringgit (MYR) according to the year } \\
\text { of assessment. }\end{array}$ \\
\hline
\end{tabular}

Table 3. Customisation of CASBEE-City (W) indicators.

Source: Author's literature reviews.

\subsection{Built Environment Efficiency (BEE) Value for Johor Bahru in 2010 and 2025}

The BEE result for Johor Bahru in 2010 is 0.99 (categorised as B-) which is 55 in the scale of 0-100 performance. Figure 2 shows the bar graphs of assessment results for quality (Q1=environmental aspects, Q2 =social aspects; Q3 = economic aspects) for Johor Bahru in 2010. 


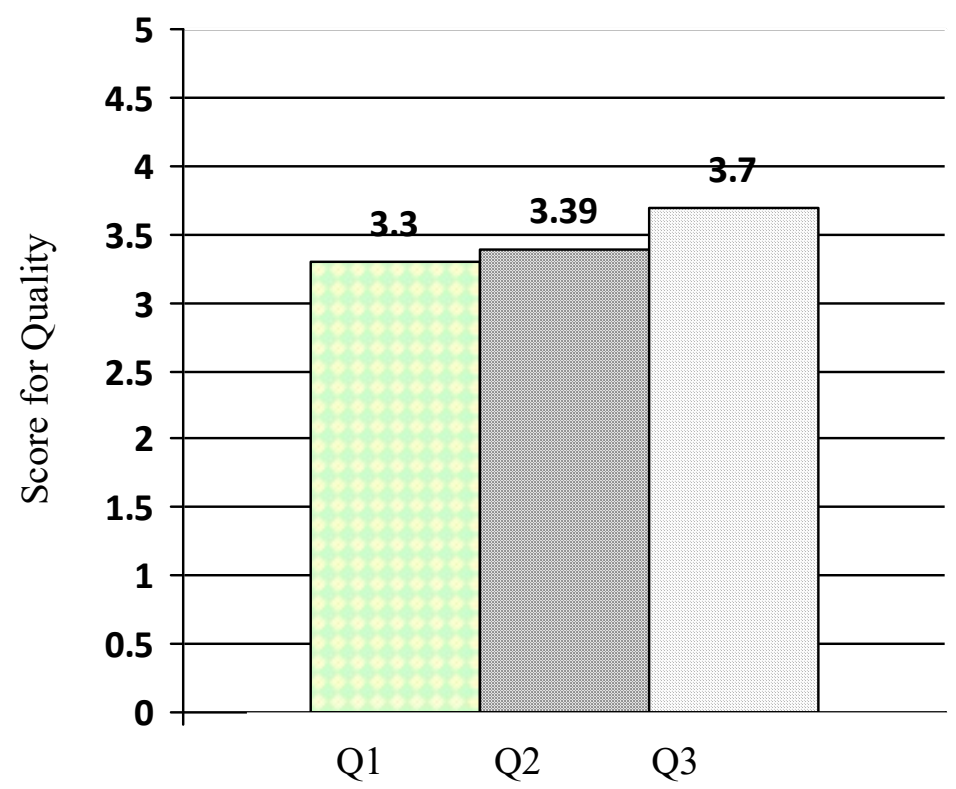

Figure 2. Bar chart of assessment results for Quality (Q1=environmental aspects, $Q 2$ =social aspects; Q3 = economic aspect) for Johor Bahru in 2010.

Figure 3 shows the assessment results for $\mathrm{Q}$ indicators in Johor Bahru. Johor Bahru is a developing commercial city and the quality score is estimated from various aspects. It can be seen clearly from the bar chart the strengths and weakness of Johor Bahru. Each Q1, Q2 and Q3 values are calculated based on assessment indicators determined in the FGD. The total 0-100 scale score are generalised in parallel with the 0.0 to 5.0 point marks in BEE chart. Johor Bahru upholds the highest score in Q3 = economic aspect (3.7/5.0) and this is a typical result for a developing commercial city [5]. Furthermore, it needs to improve its environmental and social aspects to become a sustainable commercial city in future. Figure 3 shows in details the assessment results for Q in radar chart for Johor Bahru Year 2010.

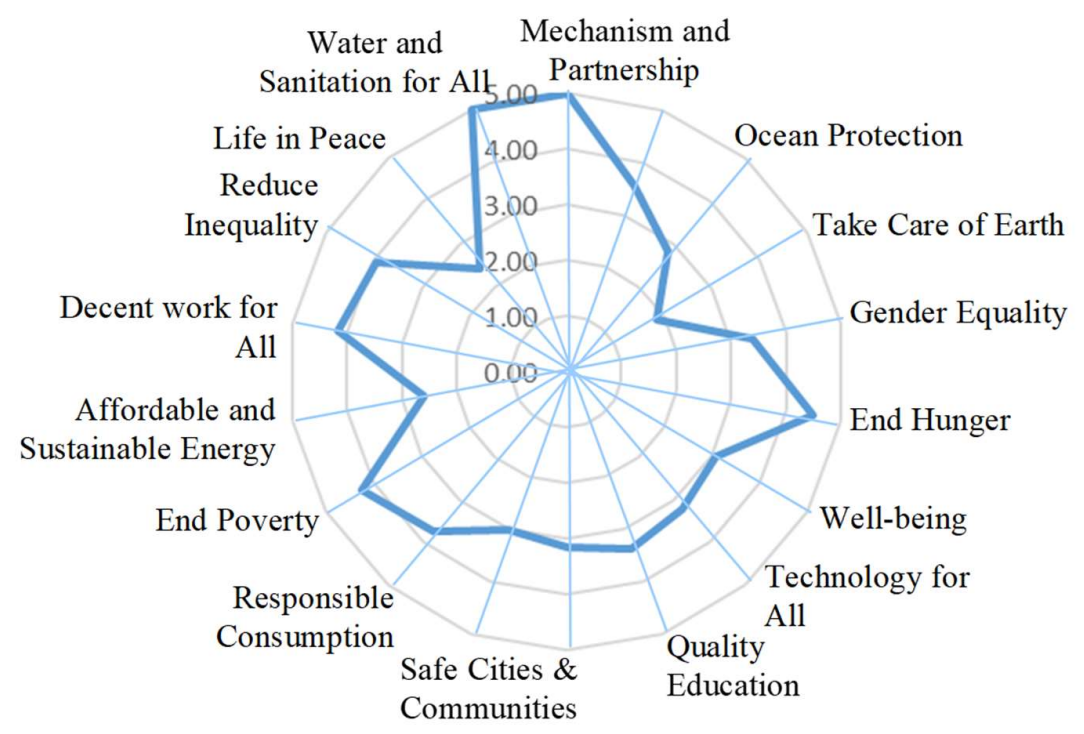

Figure 3. Assessment results for Quality (radar chart) for Johor Bahru Year 2010. 
Figure 3 shows the evaluated quality from many goals of assessment indicators for Johor Bahru Year 2010, the strengths and weakness of Johor Bahru can be understood. It shows that Johor Bahru earns highest score (5.00) in Goal 17: Mechanisms and Partnership to Reach Goals (Q2: Society). It also earns the lowest score (1.86) in Goal 15: Take Care of the Earth (Q1: Environment). Among of the assessment indicators in Goal 17 are Q17.1-Official Development Assistance (ODA) as percent of Gross National Income (GNI) and Q17.2-Evaluative Wellbeing and Positive Mood Affect. Johor Bahru needs to maintain the good quality of services provided in these aspects. Nevertheless, Johor Bahru needs to upgrade and improvise the quality of services in Goal 15. Goal 15 consists of indicators such as Q15.1Area of forest under sustainable forest management as a percent of forest area and Q15.2 -Red List Index. These two assessment indicators (Q15.1 and Q15.2) are related with the government agencies such as the Johor Forestry Department (JPNJ) and National Park, Wildlife Protection Department of Peninsular Malaysia (PERHILITAN) and private movement such as Malaysian Nature Society (MNS). The government agencies can help to improve the quality aspects of Johor Bahru in future especially in terms of protecting the area of protected forest and numbers of endangered species.

In 2025, with the current policies accounted for Johor Bahru, the BEE result is targeted to achieve 1.48 (categorised as $\mathrm{B}+$ ) which is 60 in the scale of $0-100$ performance score. Johor Bahru is targeted to increase its Quality of Life (Q) inside the city (by reviewing programs and policies provided by the local authority) and to reduce carbon emission intensity by $40 \%$ based on Low Carbon Society Blueprint for Iskadnar Malaysia (LCSBP-IM) 2025. Figure 4 shows the bar graphs of assessment results for quality (Q1=environmental aspects, Q2 =social aspects; Q3 = economic aspects) for Johor Bahru in 2025.

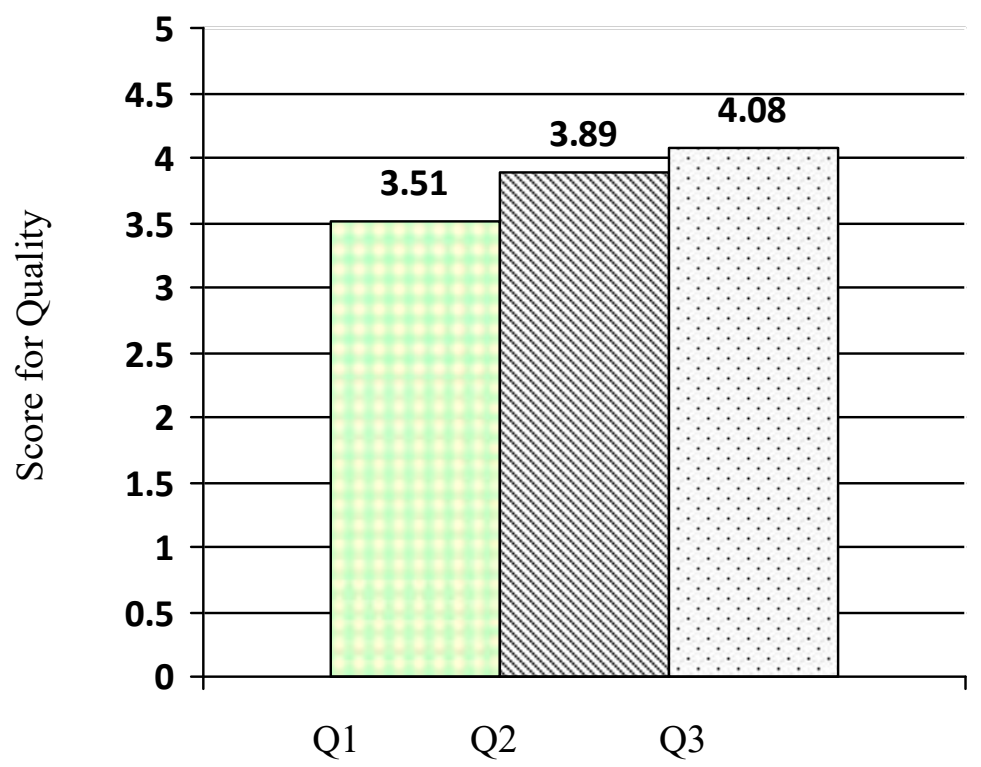

Figure 4. Bar chart of assessment results for Quality $(\mathrm{Q} 1=$ environmental aspects, $\mathrm{Q} 2$ =social aspects; Q3 = economic aspect) for Johor Bahru in 2025.

Figure 4 shows the assessment results for Quality indicators in Johor Bahru for Year 2025. By evaluating the current policies and measures that will be taken in future, the score for each Q1, Q3 and Q3 increase subsequently. Q3 = Economic aspect still holds the highest score and increase further from 3.7 in 2010 to 4.08/5.0 in 2025. Furthermore, Johor Bahru still needs to upgrade its environmental and social aspects to become a sustainable commercial city in next target future assessment year. Figure 5 shows in details the assessment results for Quality in radar chart for Johor Bahru Year 2025. 
5 of 10

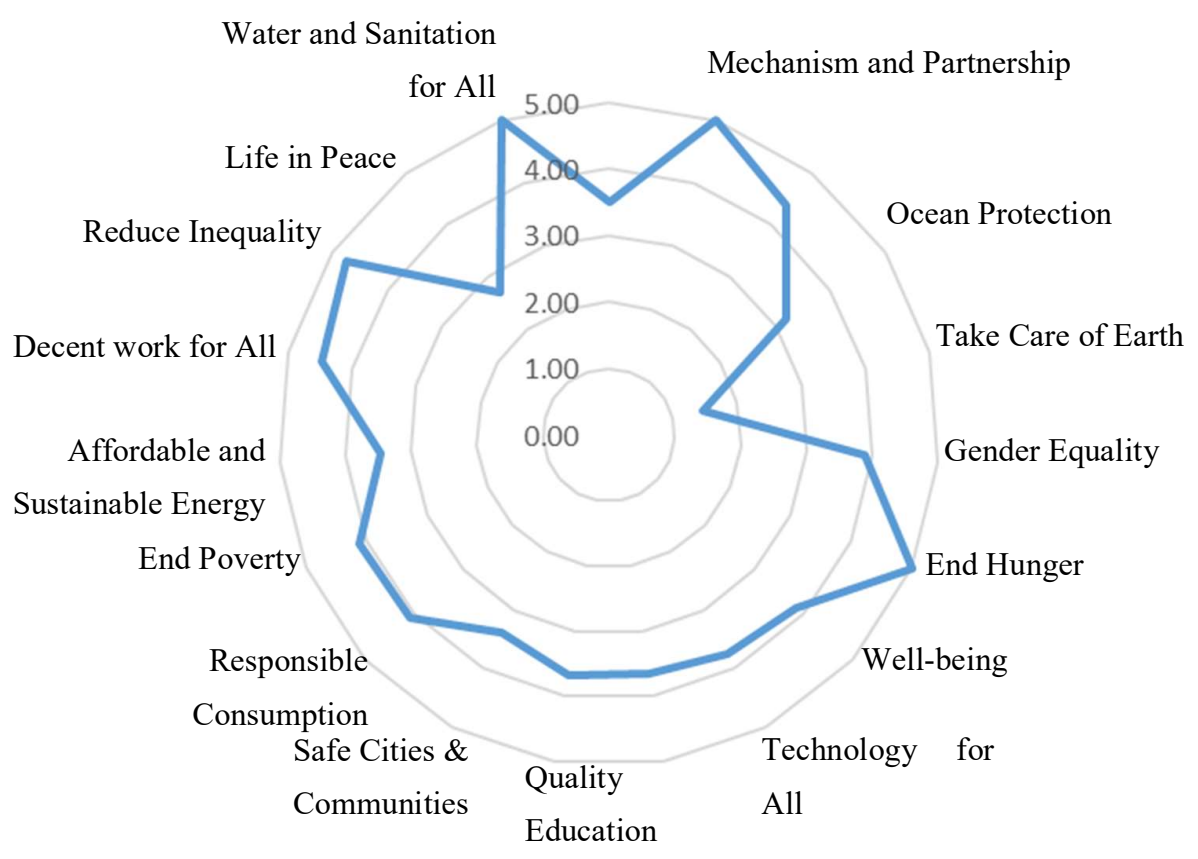

Figure 5. Assessment results for Quality (radar chart) for Johor Bahru Year 2025.

Figure 5 shows the evaluated quality from many goals of assessment indicators based on measures, policies and data input that will be taken for Johor Bahru in Year 2025. It shows that Johor Bahru has put policies and measures to earn higher scores in more aspects of goals. Johor Bahru has earned highest score in 3 Goals which are Goal 6: Water and Sanitation for all (Q1: Environment aspect), Goal 2: End Hunger (Q2: Social) and Goal 17: Mechanisms and Partnerships to reach the Goals (Q2: Social). Johor Bahru has earned the lowest score again in Goal 15: Take Care of the Earth (Q1: Environment Aspect). Unfortunately, the situation in Year 2025 still has not improved in terms of sustainable forest management and endangered species protection. Johor Forestry Department (JPNJ), National Park and Wildlife Protection Department of Peninsular Malaysia (PERHILITAN) needs to provide measures and policies to further improve this scenario in future.

\section{Conclusion and Recommendations}

Based on the research findings, most of the local authority representatives, professionals, experts and stakeholders in the FGD sessions find no major challenges for CASBEE-City (W) assessment and methodology in the context of Johor Bahru. It is also learnt that for further customisation and localisation of indicators in CASBEE-City (W) assessment for Malaysian cities, the integration of local assessment indicators into CASBEE-City (W) methodology can be conducted in future. By having the supporting citizens, urban planners, administrative officers and all stakeholders for CASBEE-City assessment, more understanding for city environmental status can be achieved towards the realisation of a low-carbon society and sustainable cities. Town and Country Planning Department (JPBD) Peninsular Malaysia can either choose to framework CASBEE-City (W) which was benchmarked with global cities or to revise the system to produce a new system called "CASBEE-City for Malaysia" which is more localised to the Malaysian context.

JPBD Peninsular Malaysia is responsible to revise the urban sustainability assessment in Malaysian cities in order to develop a comprehensive sustainability assessment framework which supports towards the low carbon management plans and programs as well supporting the national policy towards low carbon developments and society. It is no doubt that the result of CASBEE-City (W) assessment is interesting in terms of concept and methodology, but further studies with the consultation 
from local governments is needed to further continue developing the appropriate set of assessment indicators. It is also important to validate the assessment methodology and results to all stakeholders, citizens and local authorities so that they can have confidence in the results. It is hopeful that the exploration of CASBEE-City (W) method and assessment could provide alternative to Malaysian context in the field of urban sustainability assessment. Nevertheless, problems and errors in the tools methodology are needed to be overcome as to make the tools more user-friendly to encourage its usage among Malaysian local governments.

Author Contributions: conceptualisation, Muhammad Akmal Hakim; methodology, Muhammad Akmal Hakim; software, Muhammad Akmal Hakim; validation, L.W. Chau and Gabriel L.H.T; writing-original draft preparation, Muhammad Akmal Hakim; writing - review and editing, Muhammad Akmal Hakim, C.S. Ho, L.W. Chau and Gabriel L.H.T; supervision, C.S. Ho, L.W. Chau and Gabriel L.H.T; project administration, C.S. Ho; funding acquisition, C.S. Ho.

Acknowledgments: Authors would like to express the highest gratitude towards the 36 representatives who have been participating in the FGD sessions held; professional officers from Johor Bahru City Council (MBJB), Johor Bahru Tengah Municipal Council (MPJBT) and Kulai Municipal Council (MPKu) for their contribution in terms of data input, views and feedbacks. Special thanks to the representatives from Iskandar Regional Development Authority (IRDA) and Japanese experts from the Institute for Building Efficiency and Energy Conservation (IBEC), Keio University and Hosei University for the research cooperation, supervision and collaboration.

Conflicts of Interest: The authors declare no conflict of interest.

\section{References}

1. Cole, R.J. Building environmental assessment methods: Redefining intensions and roles. Building Research \& Information 2005, (35) (5), 455-467.

2. UNFCCC (United Nations Framework Convention on Climate Change). Available online: https://unfccc.int/resource/docs/convkp/conveng.pdf (accessed on 29 $9^{\text {th }}$ December 2018).

3. Ho, C.S.; Matsuoka, Y.; Janice, S.; Gomi, K., Low Carbon City in Malaysia: The Case of Development Corridor of Iskandar Malaysia. Proceedings of the First International Conference on Sustainable Urbanisation, Hong Kong, China, December $15^{\text {th }}-17^{\text {th }}, 2010$.

4. Cole, R.J.; Brown, Z.; McKay, S. Building human agency: A timely manifesto. Building Research \& Information 2005, (38) (3), 339-350.

5. Murakami, S.; Kawakubo, S.; Asami, Y.; Ikaga, T.; Yamaguchi, N.; Kaburagi, S. Development of a comprehensive city assessment tool: Casbee-city. Building Research \& Information 2011, (39) (3), 195-210, DOI: 10.1080/09613218.2011.563920.

6. OECD (Organisation for Economic Co-operation and Development). Aggregated environment indices: Review of aggregation of methodologies in use, Paris, France, 2002.

7. Roldan, A.B.; Valdes, A.S. Proposal and application of a sustainable development index, Ecol Indic. 2002, 2:251-256.

8. Atkinson, G.D.; Dubourg, R.; Hamilton, K.; Munsasignhe, M.; Pearce, D.W.; Young, C. Measuring sustainable development: Macroeconomic and the environment, Edward Elgar, Cheltenham, 1997.

9. Lee, Y.K; Huang, C.M. Sustainability index of Taipei. Environment Impact Assessment Rev. 2007, 27:505-521, [CrossRef], [Web of Science ${ }^{\circledR}$ )

10. Choon, S.W.; Siwar, C.; Joy, J.P.; Abdul Aziz Jemain; Halimaton, S.H.; Abdul Samad, H. A sustainability city index for Malaysia, Taylor and Francis Group 2011.

11. JSBC (Japan Sustainable Building Consortium). Casbee for cities technical manual, The Committee for the Development of an Environmental Performance Assessment Tools for Cities 2012. 